\title{
Flexibility in Brazilian children and adolescents: a systematic review
}

\section{Flexibilidade em crianças e adolescentes brasileiros: uma revisão sistemática}

\author{
Kenia Rejane de Oliveira Batista ${ }^{1}$ \\ Josiene de Oliveira Couto ${ }^{1}$ \\ Mona Gizelle Dreger de Oliveira \\ Roberto Jerônimo dos Santos Silva ${ }^{1}$
}

\begin{abstract}
Flexibility is a health-related physical fitness component that has its importance related to the maintenance of functional independence and achievement of activities of the daily living. This systematic review aims to analyze the existing evidence in the literature regarding physical capacity flexibility in Brazilian children and adolescents. Searches were conducted in the Virtual Health Library, Scientific Electronic Library Online, Sportdiscus databases through the EBSCOhost and Pubmed platform. There were 89,553 articles, of which 69,197 were excluded for duplicity, 20,124 for the title, 160 for the abstract, 56 after a full analysis of the article, remaining 16 articles for the qualitative analysis. Of these, from the reading of references, 57 titles partially eligible for the review were identified, and after the application of the eligibility criteria, there were only 18 for the qualitative analysis. Of the 34 studies included for the qualitative analysis, 25 studies were excluded and nine were included in the review. All articles presented the cross-sectional design and used the sit-and-reach test to assess flexibility. It was evidenced that: a) flexibility has been treated as co-adjuvant in studies with children and adolescents; b) although females have absolute flexibility values greater than the opposite sex, males have higher frequency of subjects that meet the health classification criteria in this variable; c) there is greater prevalence of the use of FITNESSGRAM and PROESP-BR reference standards.
\end{abstract}

Key words: Adolescent; Brazil; Children; Range of motion.

Resumo - A flexibilidade é um componente da aptidão física relacionada à saúde que tem importância relacionada à manutenção da independência funcional e realização das atividades da vida diária. Esta revisão sistemática tem como objetivo analisar a evidência existente na literatura quanto a capacidade física flexibilidade em crianças e adolescentes brasileiros. As buscas foram realizadas nas bases de dados Biblioteca Virtual em Saúde, Scientific Eletronic Library Online, Sportdiscus, através da plataforma EBSCOhost e Pubmed. Rastreou-se 89.553 artigos, dos quais 69.197 foram excluidos por duplicidade, 20.124 pelo titulo, 160 pelo resumo, 56 após análise integral do artigo e restaram 16 para a análise qualitativa. Destes, a partir da leitura das referências foram identificados 57 títulos parcialmente elegíveis para a revisão, após a aplicação dos critérios de elegibilidade restaram apenas 18 para a análise qualitativa. Dos 34 estudos inclusos para a análise qualitativa, 25 foram excluídos e nove estudos foram incluídos na revisão. Todos os artigos apresentaram delineamento transversal e utilizaram o teste de sentar e alcançar para avaliar a flexibilidade. Ficou evidenciado que: a) a flexibilidade tem sido tratada como coadjuvante nos estudos com crianças e adolescentes; b) embora o sexo feminino tenha valores absolutos de flexibilidade maiores que o sexo oposto, o sexo masculino tem maior frequência de sujeitos que atingem os critérios de classificação de saúde, nesta variável; c) há uma maior prevalência do uso dos padrôes de referência do FITNESSGRAM e da PROESP-BR.

Palavras-chave: Adolescente; Brasil; Criança; Amplitude de movimento articular.
1 Federal University of Sergipe. Postgraduate Program in Physical Education. Research Center on Physical Fitness, Health, and Performance of Sergipe. São Cristovão, SE. Brazil.

Received: April 27, 2018 Accepted: July 12, 2018 


\section{INTRODUCTION}

Flexibility is a health-related physical fitness component that has its importance directly related to the maintenance of functional independence and accomplishment of activities of the daily living ${ }^{1}$. Variation of its levels occurs according to stimuli ${ }^{2}$, and there may be a reduction with advancing age if there is no adequate stimulus ${ }^{3}$.

The increase and decrease of flexibility levels can be linked to several determinants, being endogenous ${ }^{4}$ or exogenous factors ${ }^{5}$. Male adolescents have higher flexibility levels at more advanced stages of maturation ${ }^{6}$ and, when comparing sexes, females have higher absolute values for this variable ${ }^{7}$. The regular practice of physical exercise improves the flexibility levels ${ }^{8}$, and sports practitioners tend to present better flexibility levels when compared to their non-practitioner peers ${ }^{9}$.

The maintenance of adequate flexibility levels is associated with the prevention of postural problems, reducing the incidence of injuries, especially in the lower back, so that insufficient flexibility levels can contribute to the reduction of functional autonomy and activities of the daily living ${ }^{10}$.

In this sense, it is important to highlight and characterize Brazilian adolescents regarding flexibility levels, mainly due to its direct relationship with physical fitness and, consequently, activities of the daily living.

Thus, this systematic review aims to analyze the evidence in the literature regarding physical capacity flexibility in Brazilian children and adolescents.

\section{METHODOLOGICAL PROCEDURES}

\section{Protocol}

The present systematic review was constructed based on the Preferred Reporting Items for Systematic Reviews and Meta-Analyses (PRISMA) methodology.

\section{Eligibility Criteria}

The question and strategy used to compose this study were based on the Population, Intervention, Comparison, Outcome (PICO) model, which is commonly used in the Evidence-Based Practice and highly recommended for the construction of systematic reviews ${ }^{11}$.

Based on the above, for the current study, Brazilian children and adolescents aged 7-18 years were used as "Population"; for "Intervention", studies that assessed flexibility and the necessary evaluation instruments were considered; for "Control", the "not applicable" criterion was adopted; and "Outcome", the existing evidence about the physical capacity flexibility in Brazilian children and adolescents in the observed studies was considered.

The following inclusion criteria were independently applied: a) original articles published in Portuguese and English language until November 2017; b) observational studies (cross-sectional, case-control and cohort); c) studies with Brazilian children and adolescents aged 7-18 years; d) studies that assessed physical fitness and flexibility and described the test/method 
used to measure flexibility; e) studies with any sample size; e) studies with STROBE $\geq 60 \%$, which considers "moderate risk of bias".

The following exclusion criteria were used: a) studies in which the population presented specific pathologies, chronic diseases or limitations; b) studies of narrative, systematic review, overview or meta-analysis; c) studies with animal models; d) those that the authors did not respond to the contact, when necessary; g) those that the abstract or full text was not found or was not available.

\section{Sources of information}

The Systematic Review was performed between November 2017 and March 2018 in the following databases: 1) Virtual Health Library (VHL); 2) Scientific Electronic Library Online (Scielo); 3) Sportdiscus, through the EBSCOhost platform; 4) PubMed.

\section{Search}

The search for eligible articles in databases was carried out using the advanced search tool available in each database using keywords through the construction of blocks of descriptors carried out by the authors. The entire search process was performed by two researchers independently and then compared for partial and total value verification. In cases where there were doubts, a third researcher was consulted.

Descriptors were inserted in Portuguese and English. The terms that composed the search were: "physical fitness"; "reference standards"; "flexibility"; "children"; "adolescents"; "fitness test". Boolean operators "AND” and "OR" were used. The first one was used to relate "keyword" blocks to each other, and the second one was used to add a word from each block in the advanced search.

For each database, the following search strategy was used: "Physical Fitness" AND "Reference Standards" AND "Pliability" OR "Flexibility" AND "Child" OR "Children" AND "Adolescent" AND "Exercise Test" AND "Brazil” OR "Brazilian” - "Physical Fitness" AND "Pliability” OR "Flexibility" AND "Child" OR "Children” AND “Adolescent” AND "Exercise Test” AND "Brazil” OR "Brazilian” - "Pliability" OR "Flexibility” AND "Child” OR "Children" AND "Adolescent" AND "Exercise Test" AND "Brazil” OR “Brazilian”.

The process of creating specific libraries (identification, exclusion of duplicate studies, division and organization of the results of each database) was performed through spreadsheet tabulation.

\section{Selection of Studies}

The selection of studies was also carried out by two researchers independently. At first, the inclusion criteria were applied for the reading of titles and abstracts. Then, the inclusion criteria were applied to full texts of articles that were selected to be read in their entirety. Because it is a peer review, in case of doubts about the inclusion of articles, both researchers discussed 
their inclusion. In cases where the doubt remained, a third researcher was consulted. The process of stratification, eligibility, selection, qualitative evaluation and studies included in the review are presented in Figure 1.

\section{Data collection process}

The process of extracting data from articles was carried out by the two researchers independently. Data were then confronted and organized into one table.

\section{Risk of bias in each study}

The process of assessing the risk of bias / methodological quality of included articles was carried out by two authors independently. The instrument used was the STROBE checklist, which includes 22 criteria to determine the risk of bias / methodological quality of studies. The instrument evaluates the quality of the observational research, making questions that help in the identification of possible risks of selection bias, information, measurement, and confounders ${ }^{12}$.

The procedure for using STROBE was according to the following parameter: for each criterion evaluated, scores were given from 0 , when the answer was "no", to 1, when the answer was "yes". At the end of classification, a score was generated for each study based on the scores of each criterion. Criteria that were not applicable for the assessed study or aspects that were not reported were excluded from the calculation to determine the final methodological quality score/risk of bias.

The quality of studies was classified as high methodological quality / low risk of bias (final score $\geq 70 \%$ ), moderate methodological quality / moderate risk of bias (final score $\geq 60 \%$ ) and low methodological quality / high risk of bias (final score $<60 \%$ ). This stage was performed by two reviewers independently and cases of disagreement were resolved by debate and in the case of maintaining the doubt, a third evaluator was consulted.

\section{RESULTS}

Figure 1 presents the flowchart that summarizes the stages of identification and selection of articles that were selected and included in this review. As inclusion and exclusion criteria were applied for the eligibility of articles, 20,124 articles were excluded by the title and 160 by the abstract, remaining 72 articles for full analysis.

Figure 1 shows that after the complete analysis, 56 studies were excluded, as follows: due to the age group of participants $(n=4)$, the nationality of the investigated population $(n=40)$, presence of individuals with some pathology $(n=6)$, review studies $(n=1)$ and for not obtaining response from the study authors $(n=5)$.

At the end of the search, 16 original articles were included for the qualitative analysis. In these, the reading of references was performed, identifying 57 titles partially eligible for revision, which was submitted to the application of eligibility criteria, remaining 18 articles for the qualitative analysis. When added 
to previously selected articles, 34 articles were included for the final qualitative analysis, of which 25 were excluded because they did not reach $60 \%$ in the STROBE evaluation and nine articles were included in the review (Figure 1).
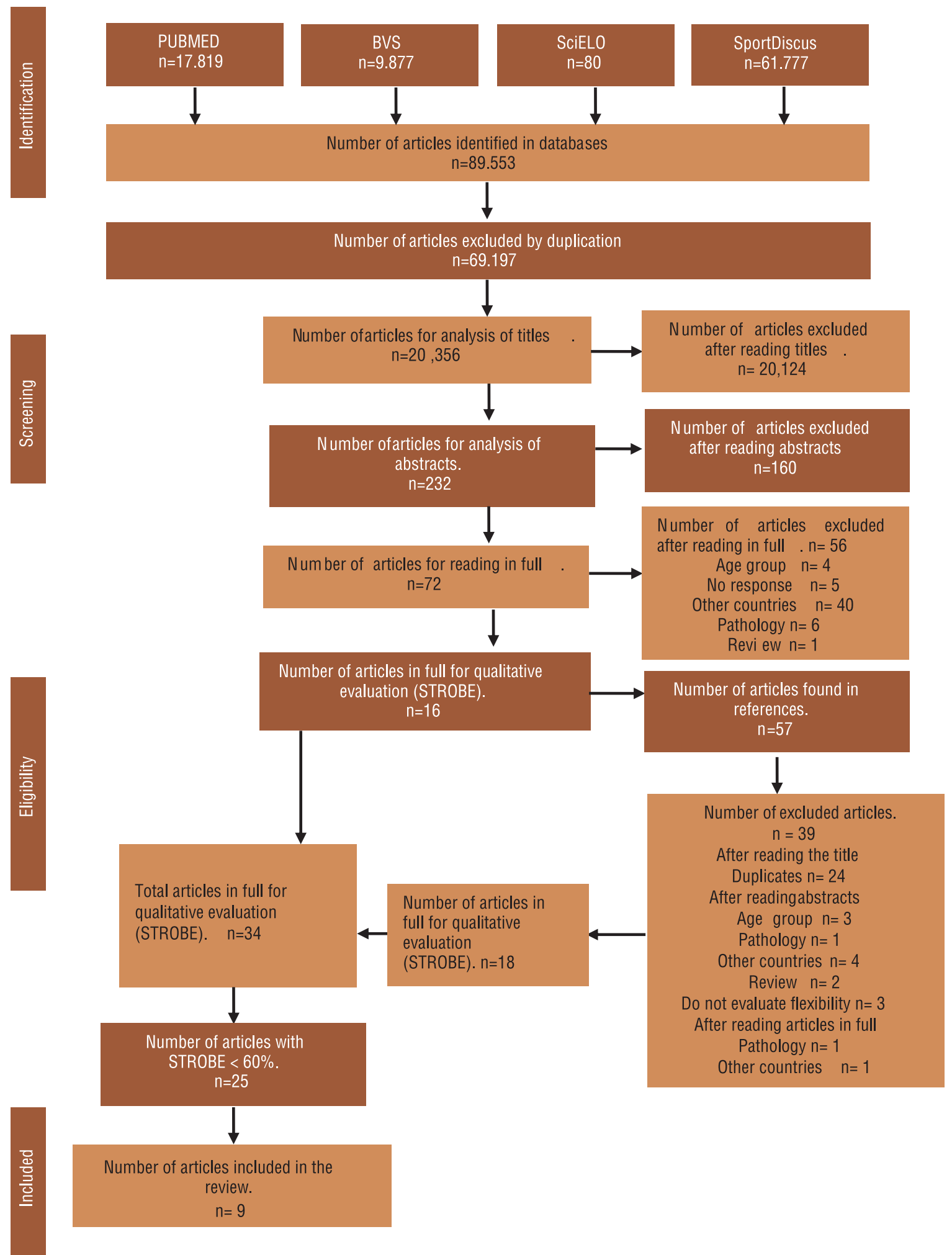

Figure 1. Study selection flowchart considering the inclusion and exclusion criteria. 
Of the nine studies included, two are part of the same study ${ }^{13,14}$, all had a cross-sectional design, seven ${ }^{13-19}$ had sample composed of both sexes and two ${ }^{20,21}$ evaluated only one sex. It was verified that $55 \%$ of studies had their sample composed only of adolescents and that sample size ranging from 129 to 2604 , totaling 9,078 subjects, of which $53.09 \%$ were female (Table 1).

Table 1 also indicates that the Southern region of Brazil presented a greater number of publications on flexibility ${ }^{13-16,21}$, and that only two studies $^{17,21}$ had primary objective directly related to flexibility, while the others had focused on physical fitness. However, it was verified that all studies evaluated the flexibility component using the same test, with adjustments required by each adopted battery.

As for the criteria adopted for the performance and classification of flexibility results, one study ${ }^{19}$ used PHYSICAL BEST, three ${ }^{13,14,18}$ used FITNESSGRAM and five studies ${ }^{15-17,20,21}$ used PROESP-BR; however, only five studies make the classification of flexibility according to criteria of adopted batteries ${ }^{14,16,18,19,21}$, and four ${ }^{14,18,19,21}$ make this classification by sex.

Table 1 also indicates that the absolute flexibility values indicate that females have higher absolute values than males; however, when considering the classification according to the reference criteria of each battery, males tend to have better prevalence values than females ${ }^{14,18,19}$. Four studies ${ }^{14,18,19,21}$ showed that more than half of adolescents had adequate flexibility levels.

Table 1. Descriptive characteristics of included studies.

\begin{tabular}{|c|c|c|c|c|c|c|}
\hline Authors & Study site & $\begin{array}{l}\text { Population } \\
\text { (age group) }\end{array}$ & $\begin{array}{l}\text { Sex } \\
(F / M)\end{array}$ & The primary aim of the study & $\begin{array}{l}\text { Battery / Test used } \\
\text { to evaluate FLEX }\end{array}$ & Outcome \\
\hline $\begin{array}{l}\text { Dumith et } \\
\text { al. }^{15}\end{array}$ & $\begin{array}{l}\text { Rio Grande/ } \\
\text { RS }\end{array}$ & $\begin{array}{l}1.132 \text { school- } \\
\text { children }(11 \pm 2 \\
\text { years) }\end{array}$ & $\begin{array}{l}311 / \\
354\end{array}$ & $\begin{array}{l}\text { To analyze the components } \\
\text { of health-related physical fit- } \\
\text { ness according to character- } \\
\text { istics such as gender, age, } \\
\text { school (public or private) } \\
\text { and geographic area (rural } \\
\text { or urban) in individuals aged } \\
7-15 \text { years }\end{array}$ & $\begin{array}{l}\text { PROESP-BR/ Sit } \\
\text { and reach }\end{array}$ & $\begin{array}{l}\text { Flexibility was greater for } \\
\text { girls, with reduction be- } \\
\text { tween } 8 \text { and } 10 \text { years and } \\
\text { reducing after this age. } \\
\text { There was no flexibility } \\
\text { classification. }\end{array}$ \\
\hline $\begin{array}{l}\text { Minatto et } \\
\text { al. }^{21}\end{array}$ & $\begin{array}{l}\text { Cascavel/ } \\
\text { PR }\end{array}$ & $\begin{array}{l}2604 \text { children } \\
\text { and adoles- } \\
\text { cents (females } \\
\text { only)(8-17 } \\
\text { years) }\end{array}$ & $\begin{array}{l}2604 / \\
N A\end{array}$ & $\begin{array}{l}\text { Compare body mass, height, } \\
\text { body mass index and flex- } \\
\text { ibility with chronological age } \\
\text { and sexual maturation and to } \\
\text { verify the influence of these } \\
\text { variables on the flexibility } \\
\text { of students from public and } \\
\text { private schools }\end{array}$ & $\begin{array}{l}\text { PROESP-BR// Sit } \\
\text { and reach }\end{array}$ & $\begin{array}{l}\text { It was verified that } \\
65.2 \% \text { of the adolescents } \\
\text { reached or surpassed the } \\
\text { zone of physical fitness. } \\
\text { There was no correlation } \\
\text { between variables body } \\
\text { mass, age, height, BMI } \\
\text { and sexual maturation } \\
\text { with flexibility. }\end{array}$ \\
\hline $\begin{array}{l}\text { Petroski et } \\
\text { al. }^{19}\end{array}$ & $\begin{array}{l}\text { Januária/ } \\
\text { MG }\end{array}$ & $\begin{array}{l}627 \text { adoles- } \\
\text { cents }(14-17 \\
\text { years) }\end{array}$ & $\begin{array}{l}361 / \\
266\end{array}$ & $\begin{array}{l}\text { To evaluate health-related } \\
\text { physical fitness (HRPF) in } \\
\text { adolescents in a city with } \\
\text { medium / low human devel- } \\
\text { opment level. }\end{array}$ & $\begin{array}{l}\text { PHYSICAL BEST/ } \\
\text { Sit and reach }\end{array}$ & $\begin{array}{l}\text { It was verified that } 59.2 \% \\
\text { of adolescents reached } \\
\text { the health criteria adopted } \\
\text { ( } 57.6 \% \text { females and } \\
60.9 \% \text { males). At the age } \\
\text { of } 14 \text { years, females had } \\
\text { inadequate flexibility levels } \\
\text { when compared to the } \\
\text { opposite sex. }\end{array}$ \\
\hline
\end{tabular}

Continue... 
.. continue

\begin{tabular}{|c|c|c|c|c|c|c|}
\hline Authors & Study site & $\begin{array}{l}\text { Population } \\
\text { (age group) }\end{array}$ & $\begin{array}{l}\text { Sex } \\
(F / M)\end{array}$ & The primary aim of the study & $\begin{array}{l}\text { Battery / Test used } \\
\text { to evaluate FLEX }\end{array}$ & Outcome \\
\hline $\begin{array}{l}\text { Guedes et } \\
\text { al. } .^{18}\end{array}$ & $\begin{array}{l}\text { Montes } \\
\text { Claros/MG }\end{array}$ & $\begin{array}{l}2849 \text { children } \\
\text { and adoles- } \\
\text { cents }(6-18 \\
\text { years) }\end{array}$ & $\begin{array}{l}1457 / \\
1392\end{array}$ & $\begin{array}{l}\text { Identify the sociodemo- } \\
\text { graphic and behavioral } \\
\text { factors most strongly asso- } \\
\text { ciated with health standards } \\
\text { based on the scores of } \\
\text { physical fitness components } \\
\text { in a representative sample of } \\
\text { Brazilian schoolchildren. }\end{array}$ & $\begin{array}{l}\text { FITNESSGRAM / } \\
\text { Sit and reach }\end{array}$ & $\begin{array}{l}\text { Met criteria established for } \\
\text { battery health standards } \\
\text { adopted } 63.4 \% \text { females } \\
\text { and } 70.7 \% \text { males. Flex- } \\
\text { ibility was more likely to } \\
\text { meet health standards for } \\
\text { males, aged }<9 \text { years, with } \\
\text { low economic level and } \\
\text { physically active. }\end{array}$ \\
\hline $\begin{array}{l}\text { Silva et } \\
\text { al. }{ }^{20}\end{array}$ & $\begin{array}{l}23 \text { states } \\
\text { of Brazil } \\
\text { plus Federal } \\
\text { District }\end{array}$ & $\begin{array}{l}1.348 \text { adoles- } \\
\text { cents (males } \\
\text { only) ( } 12.3 \pm \\
1.3 \text { years) }\end{array}$ & $\begin{array}{l}\text { NA / } \\
1.348\end{array}$ & $\begin{array}{l}\text { To compare the anthropo- } \\
\text { metric and physical fitness } \\
\text { characteristics of Brazilian } \\
\text { adolescents practicing team } \\
\text { sports and compare specific } \\
\text { parameters obtained for } \\
\text { adolescents with data from } \\
\text { the general population. }\end{array}$ & $\begin{array}{l}\text { PROESP-BR/ Sit } \\
\text { and reach }\end{array}$ & $\begin{array}{l}\text { Soccer and volleyball play- } \\
\text { ers showed better flexibil- } \\
\text { ity levels when compared } \\
\text { to basketball and handball } \\
\text { players. When comparing } \\
\text { sports practitioners with } \\
\text { the general population, } \\
\text { practitioners scored } \\
\text { higher than the general } \\
\text { population. }\end{array}$ \\
\hline \multirow[t]{2}{*}{$\begin{array}{l}\text { Minatto et } \\
\text { al. }^{13,14}\end{array}$} & $\begin{array}{l}\text { São Bonifá- } \\
\text { cio/SC }\end{array}$ & $\begin{array}{l}270 \text { adoles- } \\
\text { cents }(10-17 \\
\text { years) }\end{array}$ & $\begin{array}{l}129 / \\
141\end{array}$ & $\begin{array}{l}\text { To analyze the health-related } \\
\text { physical fitness profile } \\
\text { according to stages of sex- } \\
\text { ual maturation in Brazilian } \\
\text { adolescents (10-17 years) } \\
\text { residing in a small town of } \\
\text { Germanic colonization. }\end{array}$ & $\begin{array}{l}\text { FITNESSGRAM / } \\
\text { Sit and reach }\end{array}$ & $\begin{array}{l}\text { It was verified that male } \\
\text { adolescents belonging to } \\
\text { the more advanced stages } \\
\text { of maturation obtained } \\
\text { better results in the flex- } \\
\text { ibility test. With regard } \\
\text { to females, flexibility } \\
\text { remained stable during the } \\
\text { pubertal period. }\end{array}$ \\
\hline & $\begin{array}{l}\text { São Bonifá- } \\
\text { cio/SC }\end{array}$ & $\begin{array}{l}277 \text { adoles- } \\
\text { cents }(10-17 \\
\text { years) }\end{array}$ & $\begin{array}{l}132 / \\
145\end{array}$ & $\begin{array}{l}\text { To identify the health-related } \\
\text { physical fitness profile } \\
\text { of Brazilian adolescents } \\
\text { (10-17 years) of Germanic } \\
\text { origin and to describe the } \\
\text { prevalence of those with low } \\
\text { physical fitness according to } \\
\text { sex and age }\end{array}$ & $\begin{array}{l}\text { FITNESSGRAM / } \\
\text { Sit and reach }\end{array}$ & $\begin{array}{l}\text { It was identified that } \\
59.9 \% \text { of adolescents } \\
\text { reached the health-related } \\
\text { physical fitness criteria } \\
\text { ( } 45.5 \% \text { females and } 73.1 \% \\
\text { males) }\end{array}$ \\
\hline $\begin{array}{l}\text { Schubert } \\
\text { et al. } .^{16}\end{array}$ & $\begin{array}{l}\text { Londrina/ } \\
\text { PR }\end{array}$ & $\begin{array}{l}401 \text { children } \\
\text { and adoles- } \\
\text { cents } \\
\text { (8-16 years) }\end{array}$ & $\begin{array}{l}165 / \\
236\end{array}$ & $\begin{array}{l}\text { Identify which types } \\
\text { of sports (individual or } \\
\text { collective) may offer greater } \\
\text { benefits } \\
\text { to improve health-related the } \\
\text { physical fitness compo- } \\
\text { nents. }\end{array}$ & $\begin{array}{l}\text { PROESP-BR/ Sit } \\
\text { and reach }\end{array}$ & $\begin{array}{l}\text { Females presented greater } \\
\text { flexibility when compared } \\
\text { with the opposite sex. } \\
35.7 \% \text { of the adolescents } \\
\text { practicing some sports } \\
\text { modality, meet the health } \\
\text { criteria. No gender clas- } \\
\text { sification. }\end{array}$ \\
\hline $\begin{array}{l}\text { Joaquim } \\
\text { et al. }{ }^{17}\end{array}$ & $\begin{array}{l}\text { The inner } \\
\text { state of São } \\
\text { Paulo }\end{array}$ & $\begin{array}{l}307 \text { children } \\
\text { ( } 7-10 \text { years) }\end{array}$ & $\begin{array}{l}149 / \\
158\end{array}$ & $\begin{array}{l}\text { To verify if there is a correla- } \\
\text { tion between flexibility level } \\
\text { and agility performance in } \\
\text { school children aged } 7-10 \\
\text { years and to identify possible } \\
\text { differences in the average } \\
\text { scores of each physical capac- } \\
\text { ity and anthropometric profile } \\
\text { between boys and girls. }\end{array}$ & $\begin{array}{l}\text { PROESP-BR/ Sit } \\
\text { and reach }\end{array}$ & $\begin{array}{l}\text { No differences were found } \\
\text { for flexibility levels. There } \\
\text { was no classification by } \\
\text { gender. }\end{array}$ \\
\hline
\end{tabular}

Note. Average; \pm standard deviation; FLEX: flexibility; F: female; M: male; RS: Rio Grande do Sul; PR: Paraná; MG: Minas Gerais; SC: Santa Catarina; NA: not applicable.

As recommended by PRISMA, Table 2 indicates that of the nine studies analyzed, four ${ }^{17-19,21}$ obtained moderate risk of bias/moderate methodological quality, while the other five $\mathrm{e}^{13-16,20}$ were considered with low risk 
Table 2. Risk of bias assessment of included studies using STROBE.

\begin{tabular}{|c|c|c|c|c|c|c|c|c|c|c|c|c|c|c|c|c|c|c|c|c|c|c|c|c|c|c|c|c|c|c|c|c|c|}
\hline Authors & 1 & 1 & 2 & 3 & 4 & D & & & & & & & a & b & 12 & & & 13 & & & & 15 & a & 16 & & 17 & 18 & 19 & 20 & 21 & 22 & $\begin{array}{c}\text { Final } \\
\text { score }^{*} \\
(\%)\end{array}$ & Ranking \\
\hline $\begin{array}{l}\text { Dumith et } \\
\text { al. }{ }^{15}\end{array}$ & 0 & 1 & 1 & 1 & 1 & ) & & 1 & 1 & 1 & 1 & 1 & 1 & 1 & & 1 & 0 & 1 & 0 & 1 & 1 & 1 & 1 & 1 & 0 & 1 & 1 & 1 & 1 & 1 & 0 & 77.20 & $\begin{array}{c}\text { Low risk of } \\
\text { bias }\end{array}$ \\
\hline $\begin{array}{l}\text { Minatto } \\
\text { et al. }{ }^{21}\end{array}$ & 1 & 1 & 1 & 1 & 1 & 1 & 1 & 1 & 1 & 0 & 1 & 1 & 1 & 1 & & 0 & 0 & 0 & 0 & 1 & 0 & 1 & - & - & - & 1 & 1 & 1 & 1 & 0 & 0 & 67.86 & $\mathrm{Moc}$ \\
\hline $\begin{array}{l}\text { Petroski } \\
\text { et al. } .^{19}\end{array}$ & 1 & 1 & 1 & 1 & 1 & 1 & 1 & 1 & 0 & 0 & 1 & 1 & 1 & 1 & & 0 & 0 & 0 & 0 & 1 & 0 & 1 & - & - & - & 0 & 1 & 1 & 1 & 1 & 1 & 7.86 & $\begin{array}{l}\text { Mod } \\
\text { risk }\end{array}$ \\
\hline $\begin{array}{l}\text { Gued } \\
\text { et al. }\end{array}$ & 0 & 1 & 1 & 1 & 1 & 1 & 1 & 1 & 1 & 1 & 1 & 1 & 1 & 1 & & 0 & 1 & 0 & 0 & 0 & 0 & 1 & 1 & 0 & 0 & 0 & 0 & 1 & 1 & 1 & 0 & 1.29 & $\begin{array}{l}\text { Mod } \\
\text { risk o }\end{array}$ \\
\hline $\begin{array}{l}\text { Silva et } \\
\text { al. }{ }^{20}\end{array}$ & 1 & 1 & 1 & 1 & 1 & 1 & 1 & 1 & 1 & 0 & 1 & 1 & 1 & 1 & 0 & 0 & 0 & 0 & 0 & 0 & 0 & 1 & 1 & 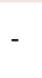 & - & 1 & 1 & 1 & 1 & 1 & 1 & 2.41 & $\begin{array}{c}\text { Low risk of } \\
\text { bias }\end{array}$ \\
\hline $\begin{array}{l}\text { Minatto } \\
\text { et al. }{ }^{13}\end{array}$ & 1 & 1 & 1 & 1 & 1 & 1 & 1 & 1 & 1 & & 0 & 1 & 1 & 1 & & 0 & 0 & & 0 & 1 & 0 & 1 & - & 1 & - & 1 & 1 & 1 & 1 & 1 & 0 & 75.86 & $\begin{array}{c}\text { Low risk of } \\
\text { bias }\end{array}$ \\
\hline $\begin{array}{l}\text { Minatto } \\
\text { et al. }{ }^{14}\end{array}$ & 1 & 1 & 1 & 1 & 1 & 1 & 1 & 1 & 1 & & 1 & 1 & 1 & 1 & & 0 & 0 & & 1 & 1 & 1 & 1 & - & - & - & 0 & 1 & 1 & 1 & 1 & 1 & 85.71 & $\begin{array}{c}\text { Low risk of } \\
\text { bias }\end{array}$ \\
\hline $\begin{array}{l}\text { Schubert } \\
\text { et al. } .^{16}\end{array}$ & 0 & 1 & 1 & 1 & 1 & 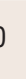 & & 0 & 1 & & 1 & 1 & 1 & 1 & & & 0 & & 0 & 1 & 1 & 1 & 1 & 1 & - & 1 & 1 & 1 & 1 & 1 & 0 & 73.33 & $\begin{array}{c}\text { Low risk of } \\
\text { bias }\end{array}$ \\
\hline $\begin{array}{l}\text { Joaquim } \\
\text { et al. }{ }^{17}\end{array}$ & 1 & 1 & 1 & 1 & 1 & 0 & & 0 & 1 & & & 1 & 1 & & & 0 & 0 & 0 & 0 & & 0 & 1 & & 1 & & 1 & 1 & 1 & 1 & 1 & 0 & 62.07 & $\begin{array}{l}\text { Moderate } \\
\text { risk of bias }\end{array}$ \\
\hline
\end{tabular}

of bias / high methodological quality, taking into account the qualitative evaluation that used STROBE as a reference.

\section{DISCUSSION}

The present study presents as main results that studies on flexibility in children and adolescents are linked to studies of physical fitness, which places flexibility in the background as a criterion to be studied in this group. It has been found that the "sit and reach" test with its variations is the test used in all studies. The study also identifies that although females have absolute flexibility values greater than the opposite sex; males have a higher frequency of subjects that meet the health classification criteria in this variable. In addition, it was verified that the FITNESSGRAM battery and that of PROESP-BR are the most used in studies and that most of the articles included in this study were carried out in the Southern region of the country.

Of articles included in this study, only two ${ }^{17,21}$ addressed flexibility as the main objective, and the others evaluated this capacity as a physical fitness component. According to Dantas and Conceição ${ }^{22}$, flexibility studies have been neglected in articles, and among health-related physical fitness components, flexibility presents a smaller number of published studies.

These results evidence the need for further studies addressing flexibility as the main point of observation in children and adolescents since this is an important component for maintaining the capacity to perform tasks of the daily living ${ }^{1}$.

Although all studies used the same test to assess flexibility (sit and reach), three studies ${ }^{13,14,18}$ followed the FITNESSGRAM standardization, 
assessing one leg at a time, while five studies followed standardization of the test used in the PROESP-BR ${ }^{15-17,20,21}$. This may be due to the fact that the test is one of the most widely used for assessing flexibility in children and adolescents, because it has an easy application, low operational cost and short duration, regardless of standardization used ${ }^{23}$.

Regarding the relationship between sexes, it was identified in studies that females present better flexibility levels when compared with the opposite sex; however, males have a greater proportion of children and adolescents who reach the health criteria for flexibility ${ }^{14,18,19}$.

Corroborating this finding, the study by Ortega et al. ${ }^{24}$ identified higher flexibility levels for females when compared to males among European adolescents. A study conducted in Latin America found similar results in children and adolescents, showing that females presented better flexibility performance when compared to the opposite $\operatorname{sex}^{23}$. On the other hand, in the study of Joaquim et al. ${ }^{17}$, no differences between sexes were found.

With regard to the proportion of subjects that meet health criteria, it may be explained by the cultural context in which there is a greater involvement of males in the practice of physical exercises when compared with the opposite $\mathrm{se}^{25}$, since the regular practice of physical exercise is related to the improvement of health-related physical fitness components ${ }^{26}$. In contrast to findings of the present study, Nogueira and Pereira ${ }^{27}$ identified a higher proportion of women who met health criteria when compared to the opposite sex.

Regarding the reference standards used in studies, it was observed that most of them used FITNESSGRAM and PROESP-BR. In this context, Guedes et al. ${ }^{28}$ points out proposals that were presented as a way of establishing cutoff points in analyses referenced by criteria such as the South Carolina Physical Fitness Test, Fit Youth Today, Physical Best and FITNESSGRAM.

In this sense, Guedes et al. ${ }^{28}$ point to proposal of FITNESSGRAM as the most accepted worldwide; however, it should be emphasized that most studies $^{15-17,20,21}$ used PROESP-BR, which was created with the objective of evaluating patterns of body development, nutritional status, healthrelated physical fitness and athletic performance in Brazilian children and adolescents ${ }^{29}$, is an interesting reference for the standardization of responses obtained in children and adolescents in the country. Regarding the location of studies, five ${ }^{13-16.21}$ of them were developed in the Southern Region of the country.

\section{CONCLUSION}

It could be concluded that flexibility is apparently not adequately analyzed in studies, since it has been treated as co-adjuvant, suggesting the masking of its real importance.

It was also evidenced that the sit-and-reach test is the most used among studies with children and adolescents and that females when compared to the 
opposite sex present better flexibility results, but that there is a greater proportion of male subjects that reach health criteria. There was a higher prevalence of the use of FITNESSGRAM and PROESP-BR reference standards.

\section{COMPLIANCE WITH ETHICAL STANDARDS}

\section{Funding}

This research was founded by Foundation for Research and Technological Innovation Support of the State of Sergipe (FAPITEC).

\section{Conflict of interest statement}

The authors have no conflict of interests to declare.

\section{Author Contributions}

Conception and definition of the study: KROB, JOC, RJSS. Conducted the survey and data collection: KROB, JOC, MGDO. Analyzed the data: KROB, JOC, MGDO, RJSS. Wrote the paper: KROB, JOC, MGDO, RJSS.

\section{REFERENCES}

1. Brito LBB, Araújo DSMS, Araújo CGS. Does flexibility influence the ability to sit and rise from the floor? Am J Phys Med Rehabil 2013;92(3):241-247.

2. Neto CF, Neto GR, Araújo AT, Sousa MS, Sousa JB, Batista GR, Reis VM. Can programme or self-selected physical activity affects physical fitness of adolescents? J Hum Kinet 2014;43(1):125-130.

3. Tremblay MS, Shields M, Laviolette M, Craig CL, Janssen I, Gorber SC. Fitness of Canadian children and youth: results from the 2007-2009 Canadian Health Measures Survey. Health Rep 2010;21(1):1-14.

4. Gonzalez-Suarez CB, Caralipio N, Gambito E, Reyes JJ, Espino RV, Macatangay $\mathrm{R}$. The association of physical fitness with body mass index and waist circumference in Filipino preadolescents. Asia Pac J Public Health 2013;25(1):74-83.

5. Pereira TA, Bergmann MLDA, Bergmann GG. Fatores associados à baixa aptidão física de adolescentes. Rev Bras Med Esporte 2016;22(3):176-181.

6. Tozetto AVB, Milistetd M, MedeirosTE, Ignachewski WL. Desempenho de jovens atletas sobre as capacidades físicas, flexibilidade, força e agilidade. Cinergis 2012;13(2):47-54.

7. Pelegrini A, Silva DAS, Petroski EL, Glaner MF. Aptidão física relacionada à saúde de escolares brasileiros: dados do projeto esporte Brasil. Rev Bras Med Esporte 2011;17(2):92-96.

8. Coledam DHC, de Arruda GA, de Oliveira AR. Efeitos de um programade exercícios no desempenho de crianças nos testes de flexibilidade e impulsão vertical. Motriz Rev Educ Fis 2012;18(3):515-525.

9. Silva JA, Silvestre TF, Silva GR, Terra GDSV, Tavares MR, Neiva CM, et al. Análise comparativa da flexibilidade, agilidade e força de membros inferiores em adolescentes praticantes e não praticantes de Taekwondo. Conexão Ci 2017;12(3):7-16.

10. Lemos ATD, Santos FRD, Gaya A CA. Hiperlordose lombar em crianças e adolescentes de uma escola privada no Sul do Brasil: ocorrência e fatores associados. Cad Saúde Pública 2012;28(4):781-788.

11. Santos CMC, Pimenta CBA, Nobre MRC. A estratégia PICO para a construção da pergunta de pesquisa e busca de evidências. Rev Latino-Am Enfermagem 2007;15(3):508-511.

12. Malta M, Cardoso LO, Bastos FI, Magnanini MMF, Silva CMFP. Iniciativa 
STROBE: subsídios para a comunicação de estudos observacionais. Rev Saúde Pública 2010;44(3):559-65.

13. Minatto G, Petroski E, Silva DAS. Gordura corporal, aptidão muscular e cardiorrespiratória segundo a maturação sexual em adolescentes brasileiros de uma cidade de colonização germânica. Rev Paul Pediatr 2013;31(2):189-97.

14. Minatto G, Petroski EL, Silva DAS. Health-related physical fitness in Brazilian adolescents from a small town of German colonization. Rev Andal Med Deporte 2016;9(2):67-74.

15. Dumith SC, Azevedo Júnior MR, Rombaldi AJ. Aptidão física relacionada à saúde de alunos do ensino fundamental do município de Rio Grande, RS, Brasil. Rev Bras Med Esporte 2008;14(5):454-459.

16. Schubert A, Januario RSB, Casonatto J, Sonoo CN. Aptidão física relacionada à prática esportiva em crianças e adolescentes. Rev Bras Med Esporte 2016;22(2):142146.

17. Joaquim AG, Santos AR, Rosa LF. Correlação entre nível de flexibilidade e desempenho na agilidade em escolares de 7 a 10 anos: um estudo transversal. Rev Bras Fisiol Exerc 2017;11(71):997-1005.

18. Guedes DP, Neto JM, Lopes VP, Silva AJ. Health-related physical fitness is associated with selected sociodemographic and behavioral factors in Brazilian school children. J Phys Act Health 2012;9(4):473-480.

19. Petroski EL, Silva AF, Rodrigues AB, Pelegrini A. Health-related physical fitness in Brazilian adolescents from areas having a medium/low Human Development Index. Rev Salud Publica 2011;13(2):219-228.

20. Silva DAS, Petroski EL, Gaya ACA. Anthropometric and physical fitness differences among Brazilian adolescents who practice different team court sports. J Hum Kinet 2013;36(1):77-86.

21. Minatto G, Ribeiro RR, Achour Junior A, Santos KD. Idade, maturação sexual, variáveis antropométricas e composição corporal: influências na flexibilidade. Rev Bras Cineantropom Desempenho Hum 2010;12:151-8.

22. Dantas EHM, Conceição MCSC. Flexibilidade: Mitos e Fatos. J Phys Ed 2017;86(4):279-283.

23. Ramos-Sepúlveda JA, Ramírez-Vélez R, Correa-Bautista JE, Izquierdo M, García-Hermoso A. Physical fitness and anthropometric normative values among Colombian-Indian schoolchildren. BMC Public Health 2016;16(1):962.

24. Ortega FB, Artero EG, Ruiz JR, España-Romero V, Jiménez-Pavón D, VicenteRodriguez G, et al. Physical fitness levels among European adolescents: the HELENA study. Br J Sports Med 2011;45(1):20-29.

25. Seabra AF, Mendonça DM, Thomis MA, Anjos LA, Maia JA. Determinantes biológicos e sócio-culturais associados à prática de atividade física de adolescentes Biological and socio-cultural determinants of physical activity in adolescents. Cad Saúde Pública 2008;24(4):721-36.

26. World Health Organization. WHO Global Recommendations on Physical Activity for Health. Geneva: World Health Organization, 2010.

27. Nogueira JAD, Pereira $\mathrm{CH}$. Aptidão física relacionada à saúde de adolescentes participantes de programa esportivo. Rev Bras Educ Fís Esporte 2014;28(1):31-40.
CORRESPONDING AUTHOR

Roberto Jerônimo dos Santos Silva Universidade Federal de Sergipe/ Departamento de Educação Física Av. Marechal Rondon S/N - Jd. Rosa Elze

São Cristovão/Sergipe - 49100-000 E-mail: rjeronimoss@gmail.com 